\title{
ОСОБЕННОСТИ КОМПОЗИЦИОННОГО СОСТАВА ТЕЛА У ЛИЦ СТАРШЕ 50 ЛЕТ
}

\author{
Некрасова Н.А., Самойлова Ю.Г., Подчиненова Д.В., Матвеева М.В., Олейник О.А. \\ ФГБОУ ВО «Сибирский государственный медицинский университет» Минздрава России, Томск
}

ЦЕЛЬ: ИзУчить особенности композиционного состава у лиц старше 50 лет.

МАТЕРИАЛЫ И МЕТОДЫ: В Исследовании приняло Участие 136 взрослых в возрасте от 50 до 82 лет. Всем был проведен комплекс обследования, включавший в себя антропометрию (рост, вес, индекс массы тела (ИМТ)) и анализ состава тела с использованием аппарата Inbody 770 (Inbody Co.Ltd, Kopeя). Статистическая обработка результатов проводилась при помощи MedCalc Statistic software.

РЕзУльтАТЫ: возраст женщин составил 60 [55,0;64,0] лет, вес 74,5 [66,3;85,2] кг, рост 159 [156,0;164,0] см, ИМТ 29,4 [25,0;33,8] кг/м². По данным биоимпедансметрии жировая масса тела составила 31,4 [21,8;39,9] кг, процент жировой массы тела 42,4 [37,2;48,0] \%, площадь висцерального жира 164,2 [127,7; 201,5] см², масса скелетной мускулатуры 23,6 [21,3; 26,0] кг, аппендикулярная мышечная масса 6,48 [5,9;7,3] кг. В группе женщин дефицит аппендикулярной мышечной массы был выявлен в 15,0\% случаев.

В группе женщин с нормальным ИМТ 78,8\% имели изменения композиционного состава тела по результатам биоимпедансометрии (увеличение жировой массы тела, процента жировой массы тела); $42,1 \%$ женщин имели висцеральное ожирение; у 52,6\% выявлен дефицит аппендикулярной мышечной массы.

Возраст мужчин составил 58,5 [50,0;65,0] лет, вес 92,4 [77,2;106,9] кг, рост 173,5 [168,0;180,0] см, ИМТ 30,9 $[25,8 ; 34,7]$ кг/M². По данным биоимпедансометрии жировая масса тела составила 26,5 [16,3;40,3] кг, процент жировой массы тела 31,8 [21,8; 39,5] \%, площадь висцерального жира 128,8 [83,6; 189,0] см², масса скелетной мускулатуры 34,6 [29,9; 40,5] кг, аппендикулярная мышечная масса 8,8 [7,9;9,2] кг. Распространенность снижения аппендикулярной мышечной массы среди мужчин составила 12,5\% случаев.

В группе мужчин с нормальным ИМТ 71,4\% имели изменения в композиционном составе тела по результатам биоимпедансометрии (увеличение жировой массы тела, процента жировой массы тела); $42,1 \%$ имели висцеральное ожирение.

ВЫВОдЫ: в ряде случаев ИМТ не отражает реальную степень жироотложения и не позволяет дифференцировать жировую и мышечную массу тела. Выявленные изменения в композиционном составе тела среди обследованных с нормальным ИМТ свидетельствуют о необходимости более активной диагностической тактики и использовании дополнительных инструментов для раннего выявления этих отклонений и их коррекции, что обусловлено их связью со снижением продолжительности и качества жизни, а так же риском развития ряда метаболических нарушений.

КЛЮЧЕВЫЕ СЛОВА: ожирение; композиционный состав тела; биоимпедансометрия; метаболический синдром. 